University of Nebraska - Lincoln

DigitalCommons@University of Nebraska - Lincoln

Publications from USDA-ARS / UNL Faculty

U.S. Department of Agriculture: Agricultural

Research Service, Lincoln, Nebraska

$1-1-2004$

Putting genes into genetic coefficients

P. Stephen Baenziger

University of Nebraska-Lincoln, pbaenziger1@unl.edu

Gregory S. McMaster

USDA-ARS, greg.mcmaster@ars.usda.gov

Wallace Wilhelm

University of Nebraska-Lincoln, wwilhelm1@unl.edu

Albert Weiss

University of Nebraska-Lincoln, aweiss1@unl.edu

Follow this and additional works at: https://digitalcommons.unl.edu/usdaarsfacpub

Part of the Agricultural Science Commons

Baenziger, P. Stephen; McMaster, Gregory S.; Wilhelm, Wallace; and Weiss, Albert, "Putting genes into genetic coefficients" (2004). Publications from USDA-ARS / UNL Faculty. 98.

https://digitalcommons.unl.edu/usdaarsfacpub/98

This Article is brought to you for free and open access by the U.S. Department of Agriculture: Agricultural Research Service, Lincoln, Nebraska at DigitalCommons@University of Nebraska - Lincoln. It has been accepted for inclusion in Publications from USDA-ARS / UNL Faculty by an authorized administrator of DigitalCommons@University of Nebraska - Lincoln. 


\title{
Putting genes into genetic coefficients
}

\author{
P. Stephen Baenziger ${ }^{a, *}$, Gregory S. McMaster ${ }^{\mathrm{b}}$, W.W. Wilhelm ${ }^{\mathrm{c}}$, \\ A. Weiss ${ }^{\text {d,1 }}$, C.J. Hays ${ }^{\mathrm{d}, 1}$ \\ ${ }^{2}$ University of Nebraska, 330 Keim Hall, Lincoln, NE 68583-0915, USA \\ ${ }^{\mathrm{b}}$ USDA-ARS, Great Plains Systems Research, 2150 Centre Avenue, Building D, Suite 200, Fort Collins, CO 80526, USA \\ ${ }^{\circ}$ USDA-ARS, Soil and Water Conservation Research Unit, 120 Keim Hall-UNL, Lincoln, NE 68583-0934, USA \\ ${ }^{\mathrm{d} U n i v e r s i t y ~ o f ~ N e b r a s k a, ~} 245$ L.W. Chase Hall, School of Natural Resource Sciences, Lincoln, NE 68583-0728, USA
}

\begin{abstract}
Plant parameters are critical inputs in crop simulation models and allow a general set of algorithms to represent features of specific cultivars. A subset of plant parameters is often referred to as "genetic coefficients". However, these genetic coefficients are developed from phenotypic observations, usually have a weak genetic basis, and are at best "genotypic" coefficients because they consider the genotype from a very integrative perspective and likely include some impact of environment on the trait or characteristic described. With increased understanding of crop genomes, we believe models can be improved by incorporating genetic coefficients that accurately describe the action of specific genes (within the genome) and therefore better represent the association between gene function and plant phenotype in simulation models. As an example, we discuss how knowledge of height genes in wheat (Triticum aestivum L.) cultivars, along with stronger genetic and environmental response algorithms, could substitute for the phenotypic parameter "height class" in the model SHOOTGRO. We also demonstrate how models containing responses based on known genetic variation can be used to identify traits to incorporate into cultivars better adapted to future climate scenarios. It remains for the geneticist, plant breeder, physiologist and modeler to cooperate and communicate with each other so that genetic information and responses with the genotype and environment and their interaction can be described in models and used to develop cultivars better able to exploit future climatic conditions.
\end{abstract}

(C) 2004 Elsevier B.V. All rights reserved.

Keywords: Climate change; Crop model; Genomics; Gibberellic acid insensitive (GAI) genes; Plant height; Photoperiod; temperature; Vernalization; Triticum; Wheat

\section{Introduction}

Crop simulation models will continue to play an essential role in assessing potential global climate

\footnotetext{
* Corresponding author. Tel.: +1 4024721538.

E-mail address: pbaenziger1@unl.edu (P.S. Baenziger).

1 Tel.: +14024726761 .
}

change impacts on agricultural systems and may also reveal traits and breeding strategies necessary to exploit projected future climate and cropping system conditions. To realize these goals, it is critical that key plant parameters are accurately represented in models. Unfortunately, crop simulation models are often limited by inaccurate or incomplete quantification of key plant parameters and associated processes 
(Ahuja and Ma, 2002; McMaster et al., 2003). Simulated results rarely reflect the wide range of actual plant responses, in part because many plant parameters and processes are based on empirical relationships that do not encompass environmental conditions under which genetic potential is fully expressed. Accurate determination of plant parameters and processes is further complicated by the potential for each genotype to interact uniquely with the environment.

Currently, crop parameters in some models are referred to as "genetic" coefficients, but these probably should be called "genotype trait" coefficients since the parameters are not directly related to genetics or genes. Some discrepancy between model output and field-observed plant responses can be considered "genetic noise"-or our failure to accurately tune the simulation to the genotype and field conditions where the observations were taken. This tuning, if done by adjusting model parameters to values that force the simulation to generate observed responses, has been criticized in the past as "tweaking" the model. However, if genetic or genotype coefficients are based on genomic data, or better yet, functional genomic data for the specific genotype observed in the field, the need for tweaking should be reduced.

With the explosion of genomics, we are identifying many of the major genes controlling important plant traits. The difficult task ahead is developing algorithms that describe plant processes based on this genomic knowledge. If these algorithms appropriately describe the plant trait or process, based on expression of genetic characteristics, the coefficients in the equation will truly become genetic coefficients.

Turning genetic "noise" into "information" is of great interest to physiologists, plant breeders and modelers. Using genomics to determine plant coefficients shows increasing promise, and unfortunately increasing complexity, as interacting genes nuance many traits.

Efforts to integrate genomics with physiology in crop models were initiated by White and Hoogenboom (1996), who estimated genetic coefficients of the BEANGRO model for common bean (Phaseolis vulgaris L.) using linear effects of seven genes. The work is particularly noteworthy in its attempt to determine whether yield predictions were improved
(Hoogenboom and White, 2003; Hoogenboom et al., $1997,2004)$. Welch et al. (2003) illustrates the pioneering work of modeling flowering time of Arabidopsis thaliana (L.) Heynh. using neural networks by applying recently derived genetic information on reproductive development. Laurie et al. (2004) expand on this topic in their discussion of work from the John Innes Centre on small-grain cereals, wheat and barley (Hordeum vulgare L.). An alternative approach from industry is briefly discussed by Campos et al. (2004).

The objectives of our perspectives paper are to illustrate and explore how new genetic knowledge obtained from molecular biology will allow development of more meaningful genetic coefficients, compared to those derived from empirical measurements. This advance in application of genomics should improve both the description of cultivars in crop simulation models and, in turn, our overall understanding of genotype by environmental interactions (GEI), as GEI impacts the development of cultivars and the management practices better adapted to future environments.

\section{Selected issues in linking genetics with physiology to determine plant parameters}

A number of important genetic concepts must be recognized to successfully link genes with genetic coefficients. Others (e.g., Hunt et al., 2003; White and Hoogenboom, 2003) have discussed these concepts in detail.

\subsection{Plant genotype and plant phenotype}

The first issue is recognition that models predict, and field observations measure the plant phenotype (the visual aspects or attributes of the plant), not the genotype. The phenotype is determined by the plant genotype (all the genes the plant contains), the environment in which it is grown, and the plasticity of the genotype response to the environment (often referred to as the genotype by environment interaction, GEI). If the goal of putting genetics into the genetic coefficients is to be achieved, efforts to model the phenotype become a matter of developing algorithms based on knowing which genes (or at 
least the most important genes) determine the phenotype, how they interact with other genes in the genotype, and how they react to the environment and the GEI. We focus on wheat plant height to illustrate how known genes determine the phenotype, interact with other genes and the environment, and affect GEI.

Plant height was chosen for several reasons. First, height is influenced by major genes that are discreet and well characterized genetically and phenotypically. Hence, although plant height is a complex trait, it is far simpler than many traits. Second, plant height is easy to quantify. Finally, the Green Revolution was based on the widespread adoption of semidwarf wheat and rice (Oryza sativa L.) cultivars and cropping practices designed to maximize grain yield using these shorter cultivars (e.g., Reynolds et al., 1999). However, environmental conditions and cultural practices influence the adoption of semidwarf cultivars. In drought-prone environments such as western Nebraska, U.S.A., tall wheat cultivars are preferred because of better seedling emergence and ease of harvest, while in eastern Nebraska where there is greater rainfall and in irrigated production systems, semidwarf wheat cultivars are preferred (Budak et al., 1995). Hence, plant height is an important consideration for many producers and plant breeders developing cultivars to meet grower needs.

A simple example of how the phenotype, in this case plant height, is affected by the genotype would be the presence of dwarfing or semidwarfing genes. Other terms are often used interchangeably with dwarfing or semidwarfing genes, such as reduced height genes $(R h t)$ or gibberellic acid insensitive genes $(G A I)$. In wheat, the semidwarfing or dwarfing genes are $R h t$ genes. Because most readers are more familiar with semidwarf wheat and semidwarfing genes, however, we will generally use those terms in this paper, while using the correct Rht gene symbols (Peng et al., 1999). These genes are pleiotropic but clearly impact plant height by reducing sensitivity to gibberellin and thus reducing internode elongation. For more details on these genes see Gale and Youssefian (1985), Reitz and Salmon (1968), Youssefian et al. (1992) and other papers listed below. Plants with dwarfing genes are shorter than near-isogenic plants without the dwarfing gene (also known as tall or conventional height plants). A near-isogenic plant contains virtually all of the genes of the dwarf plant, except for the gene at the plant height $(R h t)$ locus. Near-isogenic lines are usually developed by backcrossing (Allan, 1989). Because the dwarf and non-dwarf near-isogenic lines are virtually identical for all other genes, the differences between the two lines in the same environment can be attributed to their dwarfing gene differences. For example, Flintham et al. (1997) grew semidwarf and dwarf near-isogenic lines of 'Maris Huntsman', 'Maris Widgeon', 'Bersee', and 'April Bearded' wheat in six trials to study the effect of the dwarfing genes. The lines grew to different heights in each environment (e.g., April Bearded, a tall or conventional height cultivar, was $1.30,1.54,1.27$, $1.50,1.39$ and $1.48 \mathrm{~m}$ in Trials $1-6$, respectively).

How the genotype interacts with the environment is subtler than simply understanding a genotype response to the environment. The concept of GEI is to ascertain whether genotypes respond similarly or dissimilarly in different environments. An example of GEI for plant height is that tall wheat cultivars lose proportionately more of their maximum plant height potential in "height-limiting" environments than do semidwarf wheat cultivars (Budak et al., 1995; Weiss et al., 1995). The GEI would be non-significant if both tall and semidwarf cultivars lost proportionately the same amount of their maximum plant height potential. For simulation modeling, a significant GEI means that an algorithm must include the gene effect, the environmental effect, and the interaction of the gene effect with the environment effect. A non-significant GEI means that an algorithm would only need to account for the gene effect and the environment effect.

\subsection{Gene action}

The second important concept relevant to linking genetic coefficients with genes concerns different types of gene action. The genotype contains thousands of genes (e.g., Goff et al., 2002; Yu et al., 2002), so it is important to know how a specific gene interacts with the given genetic background (Hunt et al., 2003; Yan et al., 2003). While this field of research is too extensive to describe in detail here, the main concept can be briefly separated into two types of gene action: (1) dominant or additive effects and (2) epistasis (whether the effect of genes at one locus are masked, or enhanced, by genes at another locus). Dominant 
gene action is the interaction of two different alleles at the same locus. In hybrid and cross-pollinated crops, dominant gene effects are important because heterozygosity can occur. The model must depict the three different genotypic scenarios at a locus, namely $A A$, $A a$, and $a a$, where " $A$ " is a dominant gene and " $a$ " a recessive gene. In a cross-pollinated population, as found in many forage grasses, all three genotypes are possible. In a single cross hybrid crop (e.g., corn, Zea mays L.) made from two inbred lines, only one of the three possible genotypes at the locus is possible, but with the thousands of loci in a genotype, there would be homozygous dominant loci, heterozygous loci and homozygous recessive loci. In self-pollinated crops (e.g., wheat), heterozygosity is very rare and dominant gene action is less important. The model code needs only to describe $A A$ and $a a$. The situation would be analogous, but more complicated, for autopolyploid crops with multiple copies of the same genome (e.g., a cross-pollinated, autotetraploid would need code for AAAA, AAAa, AAaa, Aaaa, and aaaa).

A simple example of epistasis would be a plant with a gene $X$ that offers complete resistance to Disease A, while also having a second gene, gene $Y$, that also offers complete resistance to Disease A. Phenotypically plants with gene $X$ cannot be distinguished from plants with gene $Y$, nor can plants with both genes $X$ and $Y$ be distinguished from those with only one of the genes. Basically, one- and two-gene disease resistant plants are equally resistant, and the presence of one resistance gene masks the presence of the second resistance gene. In this case, an algorithm would need to describe the disease resistance response if either gene were present. The GeneGro model (White and
Hoogenboom, 1996) incorporated the recessive epistasis functioning of two photoperiod genes.

A second example of epistasis can be found in semidwarf wheat cultivars. Because wheat is an allohexaploid $(2 n=6 x=42)$ with three genomes (AABBDD), genes with similar effects can occur in different genomes. Genes commonly associated with the Green Revolution are $R h t-B l b$ (formerly $R h t_{l}$ ) and $R h t-D I b$ (formerly $R h t_{2}$ ). A semidwarf wheat cultivar has either $R h t-B 1 b$ or $R h t-D 1 b$ in the homozygous

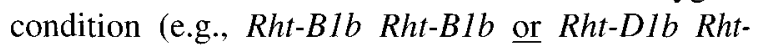
$D 1 b$ ). A full dwarf line has both $R h t-B l b$ and $R h t-D l b$ in the homozygous condition (e.g., Rht-Blb Rht-Blb and $R h t-D l b R h t-D l b)$. A full dwarf is shorter than either semidwarf but is also shorter than if the effects (in this case the proportional plant height) of the two semidwarf genes were multiplicative (Flintham et al., 1997; Table 1). Hence, the presence of one semidwarfing gene increases the effect of a second semidwarfing gene. In contrast to the previous example, an algorithm to describe this condition (plant height) would need a different response depending on whether the genotype was composed of either semidwarf gene or both semidwarf genes. Of course, there are many other semidwarfing genes, which can be used in plant breeding and possibly could be found in commercial cultivars, but the only other major gene found in commercial cultivars is $R_{h} t_{8}$ and its various alleles. With our increasing ability to determine molecularly which gene is present in a cultivar (Ellis et al., 2002; Korzun et al., 1998; Worland et al., 1998), new genetic knowledge can be used to develop genetic coefficients and algorithms that are based entirely upon the gene(s) present.

Table 1

Average height (m) of four wheat cultivars and their near-isogenic lines containing various semidwarfing and dwarfing genes grown in six trials in eastern England and central Germany based on data collected by Flintham et al. (1997)

\begin{tabular}{|c|c|c|c|c|c|c|}
\hline \multirow[t]{2}{*}{ Isoline $^{a}$} & \multicolumn{4}{|l|}{ Wheat cultivar } & \multirow[t]{2}{*}{ Mean } & \multirow[t]{2}{*}{$\%$ of tall plant height } \\
\hline & Maris Huntsman & Maris Widgeon & Bersee & April Bearded & & \\
\hline Tall (no dwarfing genes) & 0.99 & 1.09 & 1.13 & 1.41 & 1.16 & 100 \\
\hline$R h t-B I b$ & 0.84 & 0.92 & 0.99 & 1.24 & 0.99 & 86 \\
\hline$R h t-D I b$ & 0.83 & 0.88 & 0.96 & 1.19 & 0.96 & 83 \\
\hline$R h t-B I b+R h t-D I b$ & 0.56 & 0.61 & 0.65 & 0.86 & 0.67 & 58 \\
\hline$R h t-B / C$ & 0.48 & 0.58 & 0.59 & 0.654 & 0.57 & 50 \\
\hline$R h t-B l c+R h t-D l b$ & 0.40 & 0.47 & 0.49 & 0.51 & 0.47 & 40 \\
\hline
\end{tabular}

${ }^{a} R h t-B l b$ was formerly known as $R h t_{1} ; R h t-D l b$ was formerly known as $R h t_{2} ; R h t-B l c$ was formerly known as $R h t_{3}$; and $R h t-B l b$ and $R h t$. $B l c$ are allelic and the recessive allele is Rht-Bla. 


\section{Two examples linking genomics with physiology for crop simulation modeling}

\subsection{Plant height genes}

The genes important for developing useful algorithms depend largely upon what is being modeled. For example, semidwarfing genes are important for algorithms describing plant height, canopy structure, and possibly biomass and grain yield because they have pleiotropic effects on these traits (Flintham et al., 1997). Genes greatly affecting plant growth and development may be useful to improve models that predict grain yield and adaptation as primary outputs (White and Hoogenboom, 2003). These genes would include those that affect the photoperiod response (Ppd genes) and growth habit (e.g., vernalization genes, Vrm). Pugsley (1983) commented on the importance of managing these major genes ( $R h t$, $P p d, V r n)$ in monitoring grain yield and cultivar adaptation. White and Hoogenboom (2003) also believed genes controlling these traits were important for determining wheat development.

A simple attempt to develop a truly genetic coefficient is based on the data of Flintham et al. (1997) as summarized in Table 1. The "tall" (i.e. nonsemidwarf) cultivars had average plant heights ranging from 0.99 (Maris Huntsman) to $1.41 \mathrm{~m}$ (April Bearded) tall. The Rht-BIb near-isogenic semidwarfs were 0.84 (Maris Huntsman) and $1.24 \mathrm{~m}$ (April Bearded), and the Rht-D1b near-isogenic semidwarfs were 0.83 (Maris Huntsman) and $1.19 \mathrm{~m}$ (April Bearded). The full dwarf $(R h t-B 1 b+R h t-D 1 b)$ near-isogenic lines were 0.56 (Maris Huntsman) and $0.86 \mathrm{~m}$ (April Bearded) tall. The genetic background (in this case, the cultivar) can have a major effect on the phenotype of the gene(s) being studied. April Bearded and its isolines are consistently much taller than Maris Huntsman and its isolines. Interestingly, the presence of $R h t-B I b$ reduced the height of the tall genotype $12-16 \%$, indicating a similar gene effect across the four backgrounds averaged over the testing environments. The presence of $R h t-D 1 b$ reduced height 16-20\%. The full dwarf $(R h t-B l b+R h t-$ $D I b$ ) reduced the height of the tall genotype $39-44 \%$, again indicating similar gene effects across the four backgrounds. The inference derived from these results is that by knowing the genes at two loci $(R h t-B 1$ and
$R h t-D l)$, the genetic potential for height can be specified within the model for tall, semidwarf (either $R h t-B l b$ or Rht-DIb), and full dwarf (Rht-Blb+Rht$D I b$ ) genotypes. Basically knowing the height of one genotype would allow a modeler to estimate the height of the three remaining possible genotypes. As more is learned about the response of these genes to the environment, a height algorithm can also approximate the GEI effects.

The importance of understanding the genes controlling plant height can be illustrated by looking at the response of Maris Hunstman with no dwarf genes $(0.99 \mathrm{~m}$ tall $)$ and the near-isogenic semidwarf April Bearded $R h t-B I b$ (1.24 m tall). In actuality, April Bearded Rht-B1b, though being $25 \%$ taller than Maris Huntsman, will have a semidwarf response to the environment, whereas Maris Huntsman (with no dwarf genes) will have a tall wheat response. The "genetic" coefficients for these lines will be different and should reflect their genotype, leading to better simulation of the phenotype.

The above example may seem trivial, but it highlights that modelers, and to a lesser extent plant breeders, often work with limited genetic understanding. When a cultivar is developed or modeled, the breeder or modeler often knows the phenotype, but does not know the genes causing the phenotype. Until the advent of molecular markers (Ellis et al., 2002), cultivars could be grouped as being gibberellic acid sensitive or insensitive, but most cultivars were grouped into one of several relative height classes. For example in the SHOOTGRO model (McMaster et al., 1991; Wilhelm et al., 1993; Zalud et al., 2003), a wheat cultivar was considered as tall if its height was greater than $1.3 \mathrm{~m}$, medium tall if its height was 1.1$1.3 \mathrm{~m}$, semidwarf if its height was $0.95-1.1 \mathrm{~m}$, and dwarf if its height was less than $0.95 \mathrm{~m}$ tall. These measurements are for wheat grown in optimal height environments, and reductions in height under stressed conditions are treated the same for all height classes. Using the SHOOTGRO classification system, April Bearded would be a tall wheat, April Bearded $R h t-B 1 b$ (a known semidwarf wheat) would be moderately tall, Maris Huntsman (the tall version) would be considered a semidwarf wheat and Maris Huntsman Rht$B I b$ would be considered a full dwarf wheat. As the response of tall wheat genotypes and semidwarf wheat genotypes differs based on the environment (Budak et 
al., 1995), modeling plant height on the basis of known genes should reduce unexplained variation in the modeling of this trait.

Before reliable genetic markers were available, genes could be identified by crossing to known standards, but this approach was time consuming and not routinely done except for the most important genes and cultivars. Similarly, near-isogenic lines are rare and usually only found in obsolete lines due to the time and expense required to develop these lines by backcrossing.

While we have used plant height for our examples of using genetics to better define "genetic" coefficients, is it realistic to expand this example to all genetic coefficients used in wheat simulation models? As mentioned previously, Pugsley (1983) and White and Hoogenboom (2003) have suggested that wheat phenology could be largely explained by genes controlling plant height (Rht), photoperiod ( $P p d)$, and vernalization $(V r n)$. Certainly progress has been made in mapping (Laurie, 1997; Shah et al., 1999; Kato et al., 1999; Sourdille et al., 2000; Iwaki et al., 2002; Toth et al., 2003) and cloning (Danyluk et al., 2003; Peng et al., 1999; Trevaskis et al., 2003; Yan et al., 2003, 2004) these genes. In addition, some of the necessary information on the physiological aspects of these genes may be obtained from other genera. For example, Peng et al. (1999) showed that $R h t-B l$ and $R h t-D 1$, as well as dwarf-8 (d8) of corn, are orthologues of the $G A I$ gene in arabidopsis. While not wanting to minimize the difficulties of creating genetic coefficients based on genes, in the future it should be possible to develop definitive markers for important traits. With these markers and carefully developed lines, it should be possible to develop the knowledge needed to understand how genes function in specific backgrounds, how they interact with each other, and how they interact singly and collectively with the environment. This information will be used to refine genetic coefficients and, in turn, to improve crop simulation models.

\subsection{Linking genomics and simulations of crop phenology to future climate change projections}

As a second example of linking genomics and crop simulation models, we outline how simulating crop phenology might define superior genotypes based on future climatic projections and how these outcomes can be used to direct the search for trait(s) needed to accommodate or capitalize on the projected changes.

The climate change projections used in this example are based on data provided in Weiss et al. (2003). Climate change scenarios were based on two contrasting general circulation models (GCM): HADCM2 from the U.K. Center for Climate Predictions and Research (Hadley model) and the CGCM1 from the Canadian Centre for Climate Modeling and Analysis (Canadian model). Both models predict a warmer, drier climate than currently observed in the US Great Plains, but the Canadian model more so than the Hadley model.

The stochastic weather generator LARS-WG (Semenov et al., 1998) was used to generate 100 years of weather data (99 growing seasons, since winter wheat is an autumn sown crop harvested the following summer) for 2 different time periods. The first period used the monthly means and standard deviations, along with daily values, for 1961-1990 from Lincoln, NE (latitude $40^{\prime} 51^{\prime \prime} \mathrm{N}$, longitude $96^{\prime} 45^{\prime \prime} \mathrm{W}$, elevation $363 \mathrm{~m}$ ) to generate 100 years of weather data that have the same statistical properties as the original 30 -year data set. These data will be referred to as the "generated current weather". The second time period used the monthly mean and standard deviations projected for Lincoln, Nebraska for the last 30 years of this century based on both the Hadley and Canadian GCM models to generate the "future projected scenarios".

The winter wheat phenology model by Streck et al. (2003) was run using each of the three climate scenarios. Two contrasting winter wheat cultivars were used in this analysis, Arapahoe, developed in Nebraska, and Karl 92, developed in Kansas. Arapahoe reaches anthesis and physiological maturity about 4 days later than Karl 92. As simulated by the model of Streck et al. (2003), Karl 92 reaches jointing (when internode elongation begins) earlier than Arapahoe (Table 2).

Four runs were made for each cultivar: Run (1) the generated current weather data using the recommended sowing date based on Hessian fly (Mayetiola destructor Say)-free date; Run (2) the future projected weather scenarios for both the Hadley and Canadian models adjusting the sowing date for the new Hessian fly-free date based on these scenarios; Run (3) same as 
Table 2

Comparisons of two winter wheat cultivars for simulated phenological development stages of jointing, anthesis, and physiological maturity (PM) between current and future climate scenarios and changing the vernalization requirement and grain filling duration

\begin{tabular}{|c|c|c|c|c|c|c|c|}
\hline \multirow[t]{2}{*}{ Cultivar } & \multirow[t]{2}{*}{ Simulation $^{\mathrm{a}}$} & \multicolumn{3}{|c|}{ Canadian model } & \multicolumn{3}{|c|}{ Hadley model } \\
\hline & & Jointing & Anthesis & PM & Jointing & Anthesis & PM \\
\hline \multirow[t]{4}{*}{ Karl 92} & Run 1 & $38^{b}$ & 127 & 163 & 38 & 127 & 163 \\
\hline & Run 2 & 18 & 90 & 131 & 350 & 116 & 154 \\
\hline & Run 3 & 18 & 90 & 127 & 350 & 116 & 150 \\
\hline & Run 4 & 18 & 90 & 137 & 350 & 116 & 159 \\
\hline \multirow[t]{4}{*}{ Arapahoe } & Run 1 & 80 & 131 & 165 & 80 & 131 & 165 \\
\hline & Run 2 & 54 & 100 & 137 & 47 & 121 & 157 \\
\hline & Run 3 & 54 & 100 & 137 & 47 & 121 & 153 \\
\hline & Run 4 & 54 & 100 & 142 & 47 & 121 & 162 \\
\hline
\end{tabular}

Stages are reported as day of year. Future climate scenarios were for Lincoln, Nebraska and based on general circulation model outputs from the Canadian Centre for Climate Modeling and Analysis (Canadian model) and the United Kingdom Center for Climate Prediction and Research (Hadley model). Each run represents the mean of simulating 99 growing seasons.

a Run 1 uses generated data based on current climate conditions for 1961-1990 from Lincoln, Nebraska; Run 2 uses generated data for predictions of future climate conditions for Lincoln, Nebraska for 2070-2099; Run 3 reduces the vernalization requirement and increases grain filling duration by $15 \%$ for future climate conditions of Run 2 ; Run 4 is the same as Run 3, except grain filling duration was decreased by $15 \%$ of normal.

${ }^{b}$ For day of year (DOY) < 180, the DOY is in the year after planting winter wheat. For DOY > 180, the DOY is in the same year as the sowing occurs. In Nebraska, winter wheat is normally sown in autumn and harvested the following summer.

Run 2, but for a modified cultivar where the vernalization requirement was reduced to 35 vernalization days (in contrast to most current winter wheat cultivars with vernalization requirements between 40 and 50 vernalization days) and the grain filling period was increased by $15 \%$; and finally, Run (4) the same as the Run 3, except grain filling period was decreased by $15 \%$ of normal. Shorter and longer grain filling periods were considered because there is genetic variation for grain filling duration (Borner et al., 2002).

The mean day of year that both cultivars reached jointing, anthesis, and physiological maturity for each run and climate scenario is presented in Table 2. All phenological stages were reached earlier in the future projected scenario runs (Runs 2-4) than with the generated current weather (Run 1). Given the future projected scenarios were warmer, this result would be expected since thermal time $\left({ }^{\circ} \mathrm{C}\right.$ day) accumulation will increase with higher temperatures and growth stages will be reached earlier (McMaster, 1997). Change in sowing date also affected development. For Runs 2-4 and either the Hadley or Canadian models, differences in maturity were directly related to grain filling duration. Interestingly, in this analysis, jointing was reached on the same day of year for Runs 2-4 regardless of the vernalization requirement. The simulations thus imply that little effort should be made to genetically manipulate the vernalization response of winter wheat. If it is necessary to adjust the length of the period from emergence to jointing, temperature or photoperiod responses should be considered for genetic manipulation.

A critical point of this example is not that warmer temperatures hasten development, but rather there is a critical link between when a development stage is reached and extreme temperature events. For many development stages such as jointing and anthesis, either low (jointing) or high (anthesis) temperatures can strongly decrease yield. We focus on jointing in this paper to illustrate our point.

At jointing the shoot apex has switched to produce reproductive structures and is being elevated from the crown into the crop canopy (McMaster, 1997). During this time, the reproductive primordia are very sensitive to low temperatures, and normal management requires selecting cultivars that do not reach this stage until after the frost-free date in the spring. Although precisely what minimum temperature is required for what is typically called a "killing frost" differs among cultivars, environmental conditions, management practices, stage of development, hardening and 
Table 3

Number of years when simulated day of jointing occurred in the same year as sowing (i.e., in autumn) and number of occurrences of minimum temperatures less than $-3.3{ }^{\circ} \mathrm{C}$, in parenthesis, and the number of occurrences of minimum temperatures less than $-3.3^{\circ} \mathrm{C}$ in the year following sowing between jointing and anthesis and the average day of year of this occurrence for the future climate scenarios (Runs 2-4)

\begin{tabular}{|c|c|c|c|c|}
\hline \multirow[t]{2}{*}{ General circulation model } & \multicolumn{2}{|c|}{$\begin{array}{l}\text { Occurrences of fall jointing } \\
\text { (and of minimum temperatures less } \\
\text { than }-3.3^{\circ} \mathrm{C} \text { ) }\end{array}$} & \multicolumn{2}{|c|}{$\begin{array}{l}\text { Occurrences of minimum temperatures } \\
\text { less than }-3.3^{\circ} \mathrm{C} \text { between jointing and } \\
\text { anthesis (mean day of year of occurrence) }\end{array}$} \\
\hline & Karl 92 & Arapahoe & Karl 92 & Arapahoe \\
\hline Canadian model & $25(3)$ & $0(0)$ & $96(33)$ & $71(63)$ \\
\hline Hadley model & $70(4)$ & $10(0)$ & $98(11)$ & $93(51)$ \\
\hline
\end{tabular}

Future climate change scenarios were based on general circulation model outputs from the Canadian Centre for Climate Modeling and Analysis (Canadian model) and the United Kingdom Center for Climate Prediction and Research (Hadley model). Each run represents the mean of simulating 99 growing seasons.

dehardening of the plant to cold temperatures, snow cover, and other factors, we simplified the analysis by considering daily minimum temperatures less than $-3.3{ }^{\circ} \mathrm{C}$ as killing frosts.

One approach to address this possible risk is to examine the frequency of jointing occurring in autumn (Table 3). The Hadley model predicted more occurrences of autumn jointing than the Canadian model for both varieties; Karl 92, which reaches jointing before Arapahoe, had more occurrences of autumn jointing (about 25 and $70 \%$ of the years for the Canadian and Hadley models, respectively). Despite the occurrence of autumn jointing, few years in the projected future scenario had any days with temperatures less than $-3.3{ }^{\circ} \mathrm{C}$.

When examining the number of years with at least one occurrence of $-3.3{ }^{\circ} \mathrm{C}$ temperatures or less between jointing and anthesis, the Hadley model predicted slightly more occurrences than the Canadian model (Table 3). Also, the mean day of year that these low temperature events occurred was earlier for the Hadley model. Differences between the cultivars were less than for autumn jointing, but Karl 92 still had more events than Arapahoe. Regardless of cultivar or model, over $70 \%$ of the years had at least 1 day with temperatures less than $-3.3{ }^{\circ} \mathrm{C}$ between jointing and anthesis, and three of the four combinations had over $90 \%$ of the years with at least one low temperature event.

Although both GCM models predict warmer conditions in the future, temperatures of $-3.3{ }^{\circ} \mathrm{C}$ or less will continue to occur after the time of jointing for wheat grown in eastern Nebraska. We can assume that the occurrence of high temperatures, affecting pollen development and grain set near anthesis, will be another problem, particularly under future climates with higher projected temperatures. The problem of both higher and lower extreme temperatures highlighted in the foregoing discussion might be exacerbated if Schar et al. (2004) are correct that the standard deviation for temperature is underestimated by all GCMs in use today.

These results demonstrate use of simulation models with different climate scenarios to identify traits, or trait combinations, that may give a plant the potential to perform well in environments of the future. Our analyses suggest that a winter wheat ideotype for the future will require a long period from emergence to terminal spikelet/jointing to avoid low temperature injury to the meristem and earlier anthesis to avoid high temperatures injury during grain fill.

\section{Applying genomics and physiology for cultivar improvement}

Once genetics are more fully incorporated into the genetic coefficients and algorithms in crop simulation models, and runs for future possible climate scenarios have identified possible traits necessary for cultivars to thrive in future climates, a search for appropriate genes controlling these traits will be necessary. A general question that every plant breeder must ask is, "Will there be sufficient genetic variation of key traits to create these new ideotypes for improved productivity?" For three important traits for wheat (plant height, vernalization, and photoperiod), the answer will range from yes to perhaps. There is considerable 
variation for plant height considering named genes alone (Gale and Youssefian, 1985), and there are large background effects, which indicates that other genes are involved. Under warmer climate scenarios, there will certainly be adequate variation for vernalization response. There is a gradient in vernalization response from truly long vernalization requiring winter wheat grown in the Northern Great Plains to facultative winter wheat grown over the winter in California to spring wheat grown in Mexico and the northern United States. However, lack of genetic variation may be a problem in other winter cereals. For example, in Nebraska, winter barley usually survives the winter, but initiates spring growth too early and is often killed by a late, hard freeze after the shoot apex is above the soil surface (personal observations of authors). Compared to winter wheat, winter barley does not seem to have the long vernalization genotypes that would prevent this occurrence. This phenomenon reflects the freeze damage as described in Section 3.2 for wheat. Where current breeder germplasm lacks sufficient genetic variation, additional germplasm will have to be screened or sources of variation created through mutations or genetic engineering to identify or create the needed trait.

With respect to the development of new cultivars, perhaps a more troublesome aspect of climate change would be if there were greater temperature fluctuations leading to greater probability of frost damage (Schar et al., 2004). Similar to vernalization genes, there are numerous photoperiod and earliness per se genes with a gradient from photoperiod sensitivity to photoperiod insensitivity. While breeding timeframes are short compared to climate change trends, one of the most difficult problems facing plant breeders is determining what new germplasm needs to be created for climates different from the present. Most breeding programs base their success on incremental positive gains. However, future climate change may require dramatic changes in the germplasm plant breeders use, which may require plant breeders to accept short-term productivity reductions in order to create greater long-term genetic gains. Conceptually, this problem is like walking down a mountain and crossing a valley to climb a taller mountain. Crop simulation models may allow breeders to anticipate where the tallest mountains are while crossing the valleys.

\section{Looking to the future}

As we look to the future, opportunities tempered by challenges exist to improve the link between genetics and physiology in crop simulation models. By incorporating more genetics into the genetic coefficients and algorithms, we will ultimately create more accurate models that are better able to explain GEI. To do this, considerably more knowledge is needed about gene function in different environments and how genes interact with each other (epistasis). Our example of wheat plant height illustrates just one of many possible improvements that could be implemented with readily available data.

When models contain more precise genetic inputs and accurate descriptions of GEI, more reliable predictions on the impact of possible future climate change on plant development, growth, and productivity will be possible. Climate projections can then be coupled with crop simulation models to estimate future production and develop upper and lower limits for crop risk and production. Simply, using future climate and crop management scenarios in models, it will be possible to predict the type of development, function, and structure needed to optimize grain yield while minimizing producer risk. Our example of growth stage timing and risk of low temperatures addresses one of many improvements possible with current knowledge.

\section{Acknowledgements}

Partial funding for the senior author is from USDA-IFAFS competitive grant 2001-04462 and USDA, NRICGP 00-353000-9266.

\section{References}

Ahuja, L.R., Ma, L., 2002. Parameterization of agricultural system models: current approaches and future needs, Agricultural System Models in Field Research and Technology Transfer, Lewis Publishers, Boca Raton, FL.

Allan, R.E., 1989. Agronomic comparisons between $R h t_{1}$ and $R h t_{2}$ semidwarf genes in winter wheat. Crop Sci. 29, 1103-1108.

Borner, A., Schumann, E., Furste, A., Coster, H., Leithold, B., Roder, M.S., Weber, W.E., 2002. Mapping of quantitative trait loci determining agronomic important characters in hexaploid wheat (Triticum aestivum L.). Theor. Appl. Genet. 105, 921-936. 
Budak, N., Baenziger, P.S., Eskridge, K.M., Baltensperger, D., Moreno-Sevilla, B., 1995. Plant height response of semidwarf and nonsemidwarf wheats to the environment. Crop Sci. 35, $447-451$.

Campos, H., Cooper, M., Habben, J.E., Edmeades, G.O., Schussler, J.R., 2004. Improving drought tolerance in maize: a view from industry. Field Crops Res. 90, 19-34.

Danyluk, J., Kane, N.A., Breton, G., Limin, A.E., Fowler, D.B., Sarhan, F., 2003. TaVRT-1, a putative transcription factor associated with vegetative to reproductive transition in cereals. Plant Physiol. 132, 1849-1860.

Ellis, M.H., Spielmeyer, W., Gale, K.R., Rebetzke, G.J., Richards, R.A., 2002. Perfect" markers for the Rht-BIb and $R h t-D I b$ dwarfing genes in wheat. Theor. Appl. Genet. 22, $1038-1042$.

Flintham, J.E., Borner, A., Worland, A.J., Gale, M.D., 1997. Optimizing wheat grain yield: effects of $R h t$ (gibberellin-insensitive) dwarfing genes. J. Agric. Sci. 128, 11-15.

Gale, M.D., Youssefian, S., 1985. Dwarfing genes in wheat. In: Russell, G.E. (Ed.), Progress in Plant Breeding, vol. 1. Butterworths, London, pp. 1-35.

Goff, S.A., Ricke, D., Lan, T.-H., Presting, G., Wang, R., Dunn, M., Glazebrook, J., Sessions, A., Oeller, P., Varma, H., Hadley, D., Hutchinson, D., Marting, C., Katagiri, F., Lange, B.M., Moughamer, T., Xia, Y., Budworth, P., Zhong, J., Miguel, T., Paskowski, U., Zhang, S., Colbert, M., Sun, W.L., Chen, L., Cooper, B., Park, S., Wood, C., Mao, L., Quail, P., Wing, R., Dean, R., Yu, Y., Zharkikh, A., Shen, R., Sahasrabudhe, S., Thomas, A., Cannings, R., Gutin, A., Pruss, D., Reid, J., Tavtigan, S., Mitchell, J., Eldredge, G., Scholl, T., Miller, R.M., Bhatnagar, S., Adey, N., Rubano, T., Tusneem, N., Robinson, R., Feldhaus, J., Macalma, T., Oliphant, A., Briggs, S., 2002. A draft sequence of the rice genome (Oryza sativa L. ssp. japonica). Science 296, 92-100.

Hoogenboom, G., White, J.W., 2003. Improving physiological assumptions of simulation models by using gene-based approaches. Agron. J. 95, 82-89.

Hoogenboom, G., White, J.W., Acosta-Gallegos, J., Gaudiel, R.G., Myers, J.R., Silbernagel, M.J., 1997. Evaluation of a crop simulation model that incorporates gene action. Agron. J. 89, 613-620.

Hoogenboom, G., White, J.W., Messina, C., 2004. From genome to crop integration through simulation modelling. Field Crop Res. $90,145-163$.

Hunt, L.A., Reynolds, M.P., Sayre, K.D., Rajaram, S., White, J.W., Yan, W., 2003. Crop modeling and the identification of stable coefficients that may reflect significant groups of genes. Agron. J. 95, 20-31.

Iwaki, K., Nishida, J., Yanagisawa, T., Yoshida, H., Kato, K., 2002. Genetic analysis of $V R N-B I$ for vernalization requirement by using linked dCAPS markers in bread wheat (Triticum aestivum L.). Theor. Appl. Genet. 121, 400-406.

Kato, K., Mirua, H., Sawada, S., 1999. QTL mapping of genes controlling ear emergence time and plant height on chromosome 5A of wheat. Theor. Appl. Genet. 98, 472-477.

Korzun, V., Roder, M.S., Ganal, M.W., Worland, A.J., Law, C.N., 1998. Genetic analysis of the dwarfing gene (Rht8) Part I. molecular mapping of $R h t 8$ on the short arm of chromosome
2D of bread wheat (Triticum aestivum L.). Theor. Appl. Genet. 96, 1104-1109.

Laurie, D.A., 1997. Comparative genetics of flowering time. Plant Mol. Biol. 35, 167-177.

Laurie, D.A., Griffiths, S., Dunford, R.P., Christodoulou, V., Taylor, S.A., Cockram, J., Beales, J., Turner, A., 2004. Comparative genetic approaches to the identification of flowering time genes in temperate cereals. Field Crop Res. 90, 87-99.

McMaster, G.S., 1997. Phenology, development, and growth of the wheat (Triticum aestivum L.) shoot apex: a review. Adv. Agron. 59, 63-118.

McMaster, G.S., Ascough II, J.C., Shaffer, M.J., Deer-Ascough, L.A., Byrne, P.F., Nielsen, D.C., Haley, S.D., Andales, A.A., Dunn, G.H., 2003. GPFARM plant model parameters: complications of varieties and the genotype $\mathrm{X}$ environment interaction in wheat. Trans. ASAE 46, 1337-1346.

McMaster, G.S., Klepper, B., Rickman, R.W., Wilhelm, W.W., Willis, W.O., 1991. Simulation of shoot vegetative development and growth of unstressed winter wheat. Ecol. Model. 53, 189-204.

Peng, J., Richards, D.E., Hartley, N.M., Murphy, G.P., Devos, K.M., Flintham, J.E., Beales, J., Fish, L.J., Worland, A.J., Pelica, F, Sudhakar, D., Christou, P., Snape, J.W., Gale, M.D., Harberd, N.P., 1999. 'Green revolution' genes encode mutant gibberellin response modulators. Nature 400, 256-261.

Pugsley, A.T., 1983. Identification and management of major genes monitoring yield and adaptation. In: Sakamoto, S. (Ed.), Proceedings of the Sixth International Wheat Genetics Symposium, Kyoto, Japan, November 28-December 3, pp. 971-974.

Reitz, L.P., Salmon, S.C., 1968. Origin, history, and use of Norin 10 wheat. Crop Sci. 8, 686-689.

Reynolds, M.P., Rajaram, S., Sayre, K.D., 1999. Physiological and genetic changes of irrigated wheat in the post-green revolution period and approaches for meeting projected global demand. Crop Sci. 39, 1611-1621.

Schar, C., Vidale, P.L., Luthl, D., Frei, C., Haberli, C., Liniger, M.A., Appenzeller, C., 2004. The role of increasing temperature variability in European summer heatwaves. Nature 427, 332-336.

Shah, M.M., Gill, K.S., Baenziger, P.S., Yen, Y., Kaeppler, S.M., Ariyarathne, H.M., 1999. Molecular mapping of loci for agronomic traits on chromosome $3 \mathrm{~A}$ of bread wheat. Crop Sci. 39 , 1728-1732.

Sourdille, P., Snape, J.W., Cadalen, T., Charmet, G., Nakata, N., Bernard, S., Bernard, M., 2000. Detection of QTLs for heading time and photoperiod response in wheat using a doubled-haploid population. Genome 43, 487-494.

Streck, N.A., Weiss, A., Xue, Q., Baenziger, P.S., 2003. Improving predictions of development stages in winter wheat: a modified Wang and Engel model. Agric. For. Meteorol. 115, 139-150.

Toth, B., Galiba, G., Feher, E., Sutka, J., Snape, J.W., 2003. Mapping genes affecting flowering time and frost resistance on chromosome 5B of wheat. Theor. Appl. Genet. 107, 509-514.

Trevaskis, B., Bagnall, D.J., Ellis, M.H., Peacock, W.J., Dennis, E.S., 2003. MADS box genes control vernalization-induced flowering in cereals. Proc. Natl. Acad. Sci. USA 100, 13099-13104.

Weiss, A., Budak, N., Baenziger, P.S., 1995. Using transpiration to characterize plant height in winter wheat in different environments: a simulation study. Can. J. Plant Sci. 75, 583-587. 
Weiss, A., Hays, C.J., Won, J., 2003. Assessing winter wheat responses to climate change scenarios: a simulation study in the U.S. Great Plains. Clim. Change 58, 119-147.

Welch, S.M., Roe, J.L., Dong, Z., 2003. A genetic neural network model of flowering time control in Arabidopsis thaliana. Agron. J. 95, 71-81.

White, J.W., Hoogenboom, G., 1996. Integrating effects of genes for physiological traits into crop growth models. Agron. J. 88, 416-422.

White, J.W., Hoogenboom, G., 2003. Gene-based approaches to crop simulations: past experiences and future opportunities. Agron. J. 95, 52-64.

Wilhelm, W.W., McMaster, G.S., Rickman, R.W., Klepper, B., 1993. Above ground vegetative development and growth of winter wheat as influenced by nitrogen and water availability. Ecol. Model. 68, 183-203.

Worland, A.J., Korzun, V., Roder, M.S., Ganal, M.W., Law, C.N., 1998. Genetic analysis of the dwarfing gene $(R h t 8)$ in wheat. Part II. The distribution and adaptive significance of allelic variants at the Rht 8 locus of wheat as revealed by microsatellite screening. Theor. Appl. Genet. 96, 1110-1120.

Yan, L., Loukoianov, A., Blechl, A., Tranquilli, G., Ramakrishna, W., SanMiguel, P., Bennetzen, J.L., Echenique, V., Dubcovsky, J., 2004. The Wheat VRN2 gene is a flowering repressor downregulated by vernalization. Science $303,1640-1644$.
Yan, L., Loukoianov, A., Tranquilli, G., Helguera, M., Fahima, T., Dubcovsky, J., 2003. Positional cloning of the wheat vernalization gene VRNI. Proc. Natl. Acad. Sci. 100, 6263-6268.

Youssefian, S., Kirby, E.J.M., Gale, M.D., 1992. Pleiotropic effects of the GA-insensitive $R h t$ dwarfing genes in wheat. 1. Effects on development of the ear, stem and leaves. Field Crops Res. 28, 179-190.

Yu, J., Hu, S., Wang, J., Wong, G.K.-S., Li, S., Liu, B., Deng, Y., Dai, L., Zhou, Y., Zhang, X., Cao, M., Liu, J., Sun, J., Tang, J., Chen, Y., Huang, X., Lin, W., Ye, C., Tong, W., Cong, L., Geng, J., Han, Y., Li, L., Li, W., Hu, G., Huang, X., Li, W., Li, J., Li, L., Liu, J., Qi, Q., Liu, J., Liu, J., Li, L., Li, L., Wang, X., Lu, H., Wu, T., Zhu, M., Ni, P., Han, H., Dong, W., Ren, X., Feng, X., Cui, P., Li, X., Wang, H., Xu, X., Zhai, W., Xu, Z., Zhang, J., He, S., Zhang, J., Xu, J., Zhang, K., Zen, X., Dong, J., Zeng, W., Tao, L., Ye, J., Tan, J., Ren, X., Chenc, X., He, J., Liu, D., Tian, W., Tian, C., Xia, H., Bao, Q., Li, G., Gao, H., Cao, T., Wang, J., Zhao, W., Li, P., Chen, W., Wang, X., Zhang, Y., Hu, J., Wang, J., Liu, S., Yang, J., Zhang, G., Xiong, Y., Li, Z., Mao, L., Zhou, C., Zhu, Z., Chen, R., Hao, B., Zheng, W., Chen, S., Guo, W., Li, G., Liu, S., Tao, M., Wang, J., Zhu, L., Yuan, L., Yang, H., 2002. A draft sequence of the rice genome (Oryza sativa L. ssp. indica). Science 296, 79-92.

Zalud, Z., McMaster, G.S., Wilhelm, W.W., 2003. Parameterizing SHOOTGRO 4.0 to simulate winter wheat phenology and yield in the Czech Republic. Eur. J. Agron. 19, 495-507. 